\title{
Dissolved Iron Behavior in the Ravenglass Estuary Waters, An Implication on the Early Diagenesis
}

\author{
Ehsan Daneshvar \\ School of Environmental Sciences, University of Liverpool, UK \\ *Corresponding Author: e.daneshvar@liv.ac.uk
}

Copyright $(2015$ Horizon Research Publishing All rights reserved.

\begin{abstract}
Estuaries are suitable places for both clay mineral accumulation and iron trapping. Flocculated and deposited $\mathrm{Fe}$ compounds in the estuaries can lead to neo-formed minerals which they have a basic role in reservoir quality estimation. The aqueous geochemistry of the Ravenglass estuary and its feeding rivers has been studied to assess if, where and when aqueous iron is lost from the river water and accumulates as part of the sediment in the estuary. Ravenglass estuary waters are conservative mixtures between river water and seawater in terms of chloride, sodium, potassium and magnesium. Alkalinity (bicarbonate), calcium and sulphate are locally non-conservative and are affected by biological and mineral processes. The River Irt contains twice as much dissolved iron as the River Esk but all iron concentrations are much lower in the estuary samples than in the feeding rivers. Aqueous iron undergoes large-scale accumulation in the Ravenglass estuary. Iron concentrations are lowest at high tide at all sampling sites on the Ravenglass estuary. Iron concentrations are highest at low tide for the Irt arm of the estuary but are highest on the falling tide between high and low tide. Iron concentrations in estuary samples decrease rapidly as salinity increases with low iron concentrations in all estuary samples once salinity exceeds $5,000 \mathrm{mg} / \mathrm{lit}$. Iron concentrations also decrease as $\mathrm{pH}$ increases. The loss of iron is presumably due to flocculation of colloidal iron oxides, hydroxides and iron-organic complexes. Fluvial aqueous iron does not behave conservatively on mixing with seawater; most iron is lost from the water column at an early stage of river water mixing with estuary water. The site of primary iron-loss from the water occurs towards the heads of estuaries but this site will move as a function of time within the tide cycle. Given that the Esk has highest iron concentrations between high and low tide, it is likely that iron is swept from the iron-rich Irt arm of the estuary into the iron-poor Esk arm soon after high tide.
\end{abstract}

Keywords Estuaries, Flocculation, Iron Elimination, Chlorite

\section{Introduction}

The non-conservative behaviour of dissolved iron during estuarine mixing has been well documented $[6,7,16,25,35]$.

Clay minerals and organic materials in association with iron colloids are transported to estuaries by rivers, $\mathrm{Fe}$ colloids become immobilised in presence of cation during the mixing of freshwater and seawater, thus estuaries are suitable places for both clay mineral accumulation and iron trapping $[19,24,34]$. Links between Fe accumulation and clay mineral type in estuaries have been suspected $[15,24,26,29,32]$. Solid phase ferric oxides and hydroxides in the estuaries can be reduced to ferrous phases $[11,12]$. This ferrous phase depends on the density of organic materials and present or absent of sulphate behaves differently $[1,12,33,34]$.

Fluvial dissolved iron, sometimes defined as the fraction which passes through a filter size of $0.2 \mu \mathrm{m}$, comprises mostly colloidal iron on the filter papers [37]. On mixing with seawater in an estuary, these colloids are believed to aggregate to create grains that are larger than the filter pore size [25]. The aggregation of the Fe colloids is due to an interaction with cations such as $\mathrm{Mg}^{2+}$ and $\mathrm{Ca}^{2+}$ which are introduced to the estuary on an incoming tide by seawater $[7,14]$.

There have been several experimental and laboratory-based studies of fluvial $\mathrm{Fe}$ removal and aggregation [3,7,25,31,35,36,37]. Most of the research involved the experimental mixing of river water with either natural seawater or a mixture of electrolytes simulating the various ions in seawater.

Natural fluvial Fe colloids are more stable and resistant to aggregation by salt when in association with organic matter (humic acid) than synthetic iron hydroxide colloids [28], so it would be expected to not see absolute compatibility between non-conservative behaviour of $\mathrm{Fe}$ in natural fluvial systems with experiments. If organic matter were absent from river water, it has been speculated that $\mathrm{Fe}$ colloids would precipitate rapidly long before reaching the estuarine mixing zone [28]. However, in the presence of seawater ions, binding with ions and organic matter accelerates the aggregation of Fe colloids [7,28]. It has been reported that 
the salt-induced-aggregation of Fe colloids consists of at least two sequential reactions [25]; the first is fairly rapid and occurs early in the river-sea mixing process by interparticle collision and is responsible for loss of a significant portion of the iron. The second occurs more slowly over hours as $\mathrm{Fe}$ colloids continue to aggregate due to particle-particle collision [25]. Understanding how salinity varies during the tide cycle at different positions within an estuary is therefore an important step in understanding Fe behaviour in estuaries.

In contrast to laboratory experiments, in estuarine environments the distribution of dissolved iron is complicated by strong gradients of several physico-chemical-biological properties such as salinity, turbidity, temperature, dissolved oxygen concentration, $\mathrm{pH}$, and organic matter concentration. The behaviour of iron in the estuarine systems is influenced by all these parameters and the various processes involved in estuaries such as adsorption-desorption, precipitation-dissolution, sedimentation-resuspension and flocculation-coagulation $[13,21,30,31,35,37]$. One important biogeochemical process in the estuary, and in sediments at or near to the sediment surface, is bacterial sulphate reduction, since this coverts marine sulphate into sulphide which subsequently removes aqueous iron in the form of Fe-sulphide. It is also possible that sulphide minerals become oxidised (e.g. during erosion down to the sulphate reduction and sulphide precipitation zone in sediment), thus creating sulphate and, potentially, $\mathrm{Fe}$ either released into the water or making new Fe-minerals (such as siderite or Fe-clay minerals)

Water circulation in an estuary is typically controlled by topography, tidal currents and range, and the volume of fresh water discharged from rivers. The transition from fresh to salt water (estuary characteristic) causes some changes in the dissolved and suspended load of rivers [20,40]. The most important physical effect is flocculation. Clay minerals, organic matter, and colloidal hydroxides of iron all tend to form stable suspensions in fresh water, but tend to flocculate and sink in seawater [7,17,35]. Depending on the type of estuary and the specific details of the mixing of saline and fresh water in an estuary, the floccules either sink to the sediment surface and settle or they are transported to the sea, e.g. as bedload [13].

Clay minerals and organic matter as well as iron colloids are transported to estuaries by rivers; clay minerals tend to undergo ion-exchange. Iron becomes mobilised in the presence of cations within the mixing zone of freshwater and seawater, so estuarine natural water [22] is a suitable place for clay mineral alteration processes (and specifically ion exchange) and $\mathrm{Fe}$ flocculation.

In terms of the reservoir quality assessments and clay mineral alteration and neoformation of Fe-rich clay minerals in estuaries [26], this research was designed to address the way aqueous $\mathrm{Fe}$ varies in the Ravenglass estuary as function of salinity and water chemistry. The specific questions being addressed are:

How do salinity and water geochemistry vary at different sites within the Ravenglass estuary during the tide cycle?

Is Ravenglass estuary water a conservative mixture between river water and seawater, or do geochemical processes further alter the estuary water composition?

How does dissolved iron vary at different sites within the estuary during the tide cycle?

How does the concentration of dissolved iron change when river water enters the estuary?

Does fluvial dissolved iron behave conservatively on mixing with seawater?

\section{Materials and Methods}

The Ravenglass estuary is a local name for an area which encompasses the tidal reaches of the Rivers Esk, Irt and Mite. The estuary is located on the Cumbrian coast in the north-west of England (Fig. 1). A single channel connects the confluence of the three rivers to the sea.

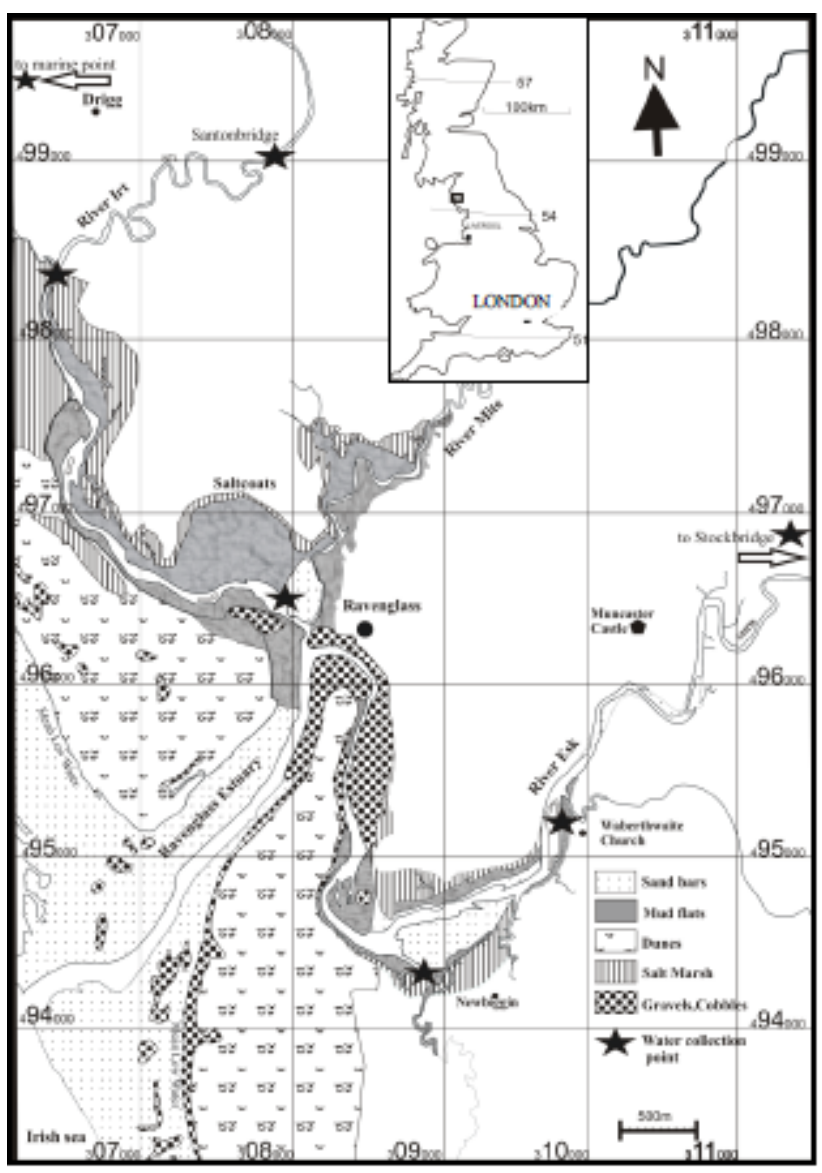

Figure 1. The Ravenglass estuary and sub estuaries: Irt, Mite and Esk. Location of the water sample stations in the estuaries and end-members.

The Ravenglass Estuary is a macro-tidal estuary, with a tidal range of over $7 \mathrm{~m}$ on spring tides. The estuary has relatively high tidal discharges and velocities but the rivers that feed into it have relatively low discharges [2]. The estuary thus largely empties of water at low tide.

The evolutionary of geological issue in this estuary has 
been shown its present morphology, and follows the global rise in sea level following melting of the ice after the last glaciations [5]. The Rivers Esk and Irt are primarily fed by small streams from the surrounding hill draining the Eskdale granite [27] and the St. Bees Lower Triassic sandstone Sherwood sandstone Group; [41] respectively.

\section{Sampling Methods}

Water samples from the Ravenglass estuary were collected at various sites at regular intervals through the tidal cycle in the summer of 2009 , in sunny normal day. Six stations were selected for water sampling including four sites for estuary waters and two fluvial end member sites and a coastal site about $1000 \mathrm{~m}$ north of the where the Ravenglass estuary meets the open sea. For each estuary (Irt and Esk arms of the Ravenglass estuary), fresh-water dominated and marine-water dominated sites subject to availability and easy access, were chosen. In the Irt estuary, the Irt estaury-upper site is fresh water-dominated and the Irt estaury-lower site is marine water-dominated. In the Esk estuary, the Newbiggin bridge (hereafter known as Esk estuary-lower) is marine water-dominated and the Waberwaith Church (Esk estaury-upper) is fresh water-dominated. In addition, Santonbridge from the River Irt and Stockbridge from the River Esk were chosen in order to characterise the fluvial (fresh water) end-members.

A site at Driggholme beach, about $1000 \mathrm{~m}$ north of the point where the Ravenglass estuary meets the sea, was chosen to sample the marine water end-member.

Twelve estuary water samples were taken during tide cycles for 12 hours at each estuary station. The end-members at Santonbridge, Stockbridge and Driggholme were collected on the same sampling mission. The extra end-members from Santonbridge and Stockbridge were collected later immediately after a storm event.

Water samples were initially collected in 1 gallon polythene canisters by wading out into the estuary (or river or the sea) until the water depth was about $1 \mathrm{~m}$. These canisters were half filled with the water from the site and then capped, shaken and emptied. The canisters were then filled to the brim by immersing the neck about $50 \mathrm{~cm}$ below the water surface. The canisters were capped and taken to a mobile laboratory (the back of a Ford Transit van) for processing. Note that working in estuaries carries peculiar risks and suitable personal protective equipment was employed during sample collection including; chest-high waders, life jacket, and, in some cases a rope held firmly by a colleague standing on the bank of the estuary.

All water samples were stored in air-tight polyethylene jars that were filled to the brim. Four types of sample were carefully prepared on-site (i.e. in the back of the van), from each site and at each time, for further chemical analysis.

Raw sample: $500 \mathrm{ml}$ water samples preserved in a PE jar as an untreated (unfiltered-unacidified) sample.

Filtered-acidified: $500 \mathrm{ml}$ raw water samples were filtered using NALGENE filteration set jars in the field, using $0.2 \mu \mathrm{m}$ Whatman cellulose nitrate filters, under pressure using a car battery-driven simple Fisher brand vacuum pumps. Suspended particles and large floccules remained on the filter papers. The samples were acidified with $1 \%$ analytical grade nitric acid to reach $\mathrm{pH} \sim 3$. These types of sample were intended for cation analysis and possibly also iron determination.

Filtered-unacidified: $500 \mathrm{ml}$ raw water samples were filtered in the field, using $0.2 \mu \mathrm{m}$ Whatman cellulose nitrate filters, under pressure using car battery driven simple vacuum pumps. These samples were left at its natural $\mathrm{pH}$ and were intended for anion analysis in the laboratory.

Acidified-filtered: a $500 \mathrm{ml}$ raw water sample was acidified with $1 \%$ nitric acid to reach the $\mathrm{pH} \sim 2$. These samples were then filtered using NALGENE filteration set jars in the field, using $0.2 \mu \mathrm{m}$ Whatman cellulose nitrate filters, under pressure using a car battery-driven simple Fisher brand vacuum pumps. These samples were prepared for iron analysis and were designed to monitor the concentration of aqueous and colloidal iron in the water.

All samples were frozen for further geochemical analysis in the laboratory.

\section{Field Analysis Methods}

Determination of $\mathrm{pH}$, temperature and alkalinity were made as quickly as possible (typically with 15-20 minutes), on site, using unfiltered raw samples. $\mathrm{pH}$ and alkalinity were measured with an automated alkalinity meter. The 848 Titrino Plus is a titrator for volumetric titrations for universal applications which is manufactured by Metrohm Company. This titrator was used under Monotonic equivalence point titration (MET) conditions in which the reagent (sulphuric acid $0.01 \%$ ) was added in constant volume steps by the titrator and $\mathrm{pH}$ was continuously measured.

\section{Laboratory Analysis Methods}

All major anions and cations were analysed using ion chromatography (IC). The instrument used was a Metrohm Compact IC Pro 881. The instrument was used for ion chromatography determination of anions with sequential suppression and without the suppression for the determination of cations. The instrument was operated with MagIC Net software 2.1.2. MagIC Net controls and monitors the IC instrument, evaluates the measured data (quality control) and administers it in a database. All water samples were filtered $(2 \mu \mathrm{m})$ before analysis with IC. Filtered, unacidified samples were analysed using a Metrospe A Supp 5-250 column for anion analysis with an eluent of sodium carbonate and bi-carbonate. Filtered acidified samples were analysed using a Metrosep C4 150 column for cation analysis using an eluent of $1 \%$ nitric acid and $4.6 \mathrm{mM} \mathrm{H}_{3} \mathrm{PO}_{4}$.

Calibration was set before anion and cation analysis. Quantification in IC requires a calibration that covers the defined measuring range. The necessary calibration standards were prepared from a concentrated standard by appropriate manual dilution. Calibration was run with standard solutions in steps of $1,5,10,50,100$ and $200 \mathrm{mg} / \mathrm{L}$ of each species to be determined, diluted from an original 
stock of $1000 \mathrm{mg} / \mathrm{L}$. MagIC Net controls all data and components of the intelligent IC. The combination of software and hardware allows the system to compare results and shows graphs and statistic of calibration pattern. Calibration method was done to appropriate $(\mathrm{R} 2>=0.999)$ levels for all anion and cation analyses.

Iron concentration in the acidified-filtered samples was measured at Manchester University. Fe was determined using a VG Elemental "Horizon" inductively coupled plasma-optical emission (ICPOES) instrument, following appropriate dilutions.

\section{Results}

\section{pH and Alkalinity}

Alkalinity and $\mathrm{pH}$ are two parameters that provide insight into changing water geochemistry in an estuary. Both can be determined by simple tests. $\mathrm{pH}$ and alkalinity influence the estuarine carbon cycle, which involves the movement of carbon from the atmosphere into plant and animal tissue and into water bodies $[10,42]$. The $\mathrm{pH}$ of water is the measure of how acidic or basic it is and it is a master variable controlling chemical speciation in natural waters. Figure 2 shows the $\mathrm{pH}$ measurement for the four stations in the Esk and Irt branches of the Ravenglass estuary through tide cycles. The highest $\mathrm{pH}$ in the all stations occurs approximately at high tide for the less marine Irt estaury-upper and Esk estuary-upper sites. The lowest $\mathrm{pH}$ roughly corresponds to low tide conditions. The more marine-dominated parts of the Irt estuary at Irt estaury-lower and the Esk estuary at Esk estuary-lower have less variable and higher $\mathrm{pH}$ than the up-estuary sites. This pattern is in accord with the fact that the Rivers Esk and Irt have $\mathrm{pH}$ values of 6.8 and 7.4, respectively, and the nearby seawater sample has a $\mathrm{pH}$ of 8.7 (Table 1). Thus low tide estuary samples, at least high up the estuary, appear to be river water-dominated while the high tide samples and the more sites closer to the sea tend to be seawater-dominated.

Alkalinity is a measure of water's capacity to neutralize acids and in natural estuary waters is influenced by the presence of alkaline compounds in the water such as bicarbonates, carbonates, and hydroxides [13]. Alkalinity is reported as $\mathrm{mg} / \mathrm{l}$ of bicarbonate $\left(\mathrm{HCO}^{-}{ }^{-}\right)$. The alkalinity of the Rivers Esk and Irt is 10 and $14 \mathrm{mg} / \mathrm{l}$ respectively, while the nearby seawater has an alkalinity of $126 \mathrm{mg} / \mathrm{l}$ (Table 1). The alkalinity behaviour in the Irt and Esk estuaries (Fig. 2) broadly follows $\mathrm{pH}$ in that it increases at high tide and decreases in a falling tide. The lowest alkalinity occurs at low tide. The two estuary sites closest to the sea develop higher alkalinities than the incoming seawater and have much greater alkalinity than the two sites furthest from the sea (most up-estuary; Fig. 2).

Table 1. Chemical composition of the end-members. Fresh water was collected beyond the high tide line in each estuary and a marine sample, Stockbridge on the Esk River, Santon Bridge on the Irt River and a coastal path from the Drigg LLNW site for the marine point (marine Fe

concentration taken from Bousher, 1999). The fluvial Fe concentrations are from samples that were acidified to $\sim \mathrm{pH} 2$ and then filtered through a $0.2 \mu \mathrm{m}$ filter.

\begin{tabular}{|c|c|c|c|}
\hline & River Esk & River Irt & Marine point \\
\hline Ions (mg/lit) & (Stock bridge) & (Santen bridge) & (Driggholme) \\
\hline $\mathrm{Na}$ & 9.41 & 11.27 & 8816.90 \\
\hline $\mathbf{K}$ & 1.18 & 2.49 & 352.15 \\
\hline $\mathrm{Mg}$ & 283 & 3.93 & 125215 \\
\hline $\mathrm{Ca}$ & 8.82 & 22.33 & 399.85 \\
\hline $\mathrm{C} 1$ & 24.40 & 40.55 & 18004.00 \\
\hline $\mathrm{SO} 4$ & 11.19 & 2264 & 2497.10 \\
\hline Fe & 0.29 & 0.67 & 001 (filtered) \\
\hline Alkalinity & 10.01 & 13.80 & 1255 \\
\hline $\mathrm{pH}$ & 6.82 & 7.41 & 8.67 \\
\hline
\end{tabular}

\section{Results of Major Cation and Anion Analysis}

As would be expected, chloride is relatively low in the two river water samples ( $24 \mathrm{mg} / \mathrm{l}$ in the Esk and $40 \mathrm{mg} / \mathrm{l}$ in the Irt) and, of course, is highly concentrated in the nearby seawater sample (18 g/l; Table 1). Chloride concentration increases rapidly at high tide and then fall towards low tide (Fig. 2). The two estuary sites closest to the sea develop higher chloride concentrations than the incoming seawater and have much higher chloride concentrations than the two sites furthest from the sea (most up-estuary; Fig. 2).

To illustrate the co-variation of the analysed cations and anions, the $\mathrm{Na}$ and $\mathrm{Cl}$ concentrations were divided by 10 (to prevent those two elements obscuring changes in the less concentrated elements) and then all were plotted as concentration as a function of time through the tide cycle at each site (Figs. 3 and 4). These diagrams beautifully illustrate how composition of estuary water varies with time during tide cycles. 

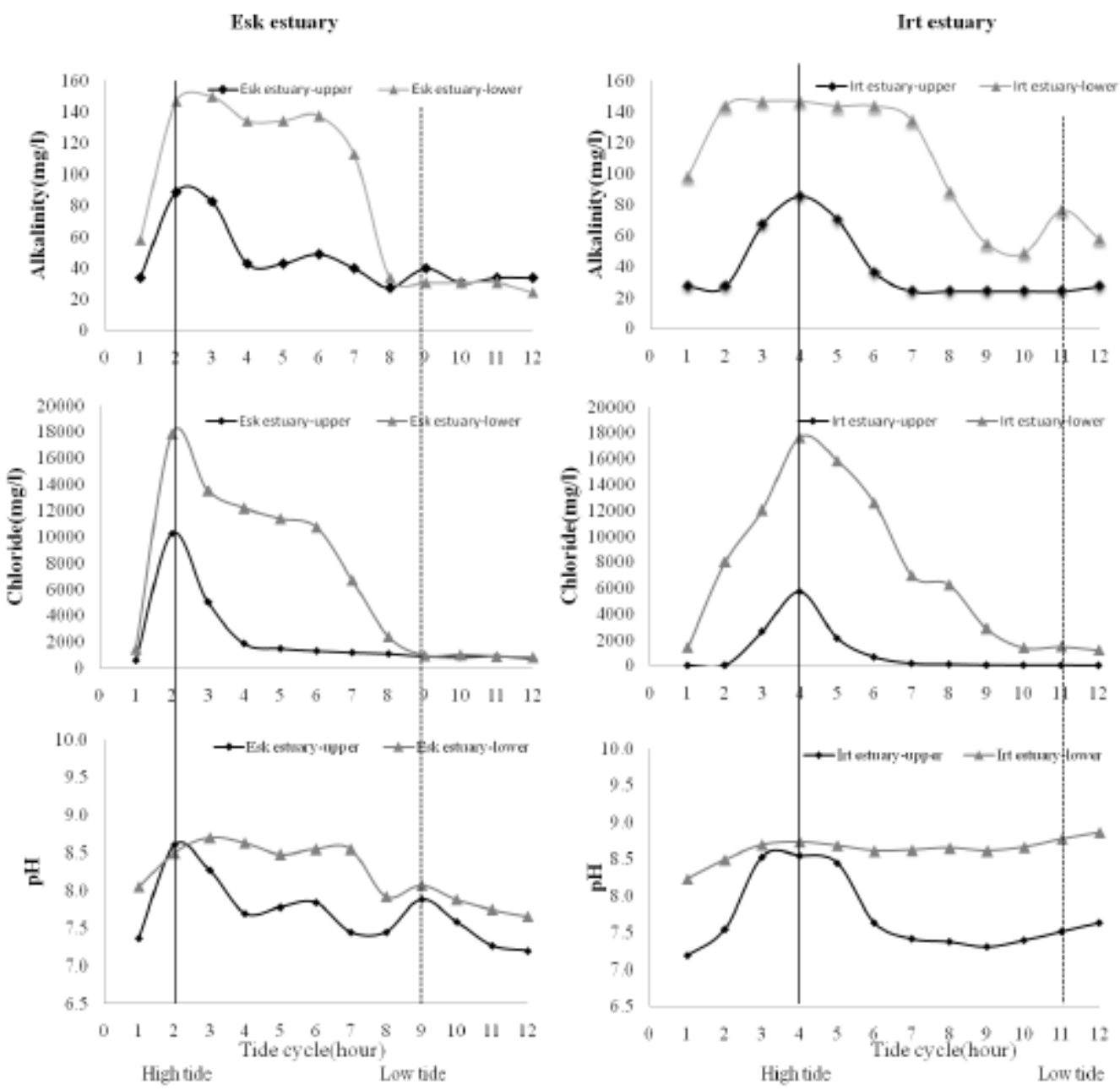

Figure 2. Alkalinity, $\mathrm{pH}$ and chloride concentration of the samples during 12 hours tide cycle sampling in the Irt estuary (right) stations (Irt estaury-lower and upper) and Esk estuary (left) stations (Esk estaury-lower and Esk estuary-upper). Irt estaury-lower and Esk estaury-lower are the marine-dominated part of their estuaries. Irt estaury-upper and Esk estuary-upper are the fresh water-dominated part. The marine water-dominated samples show a broad peak around high tide while the fresh-dominated samples had a sharp peak at high tide.
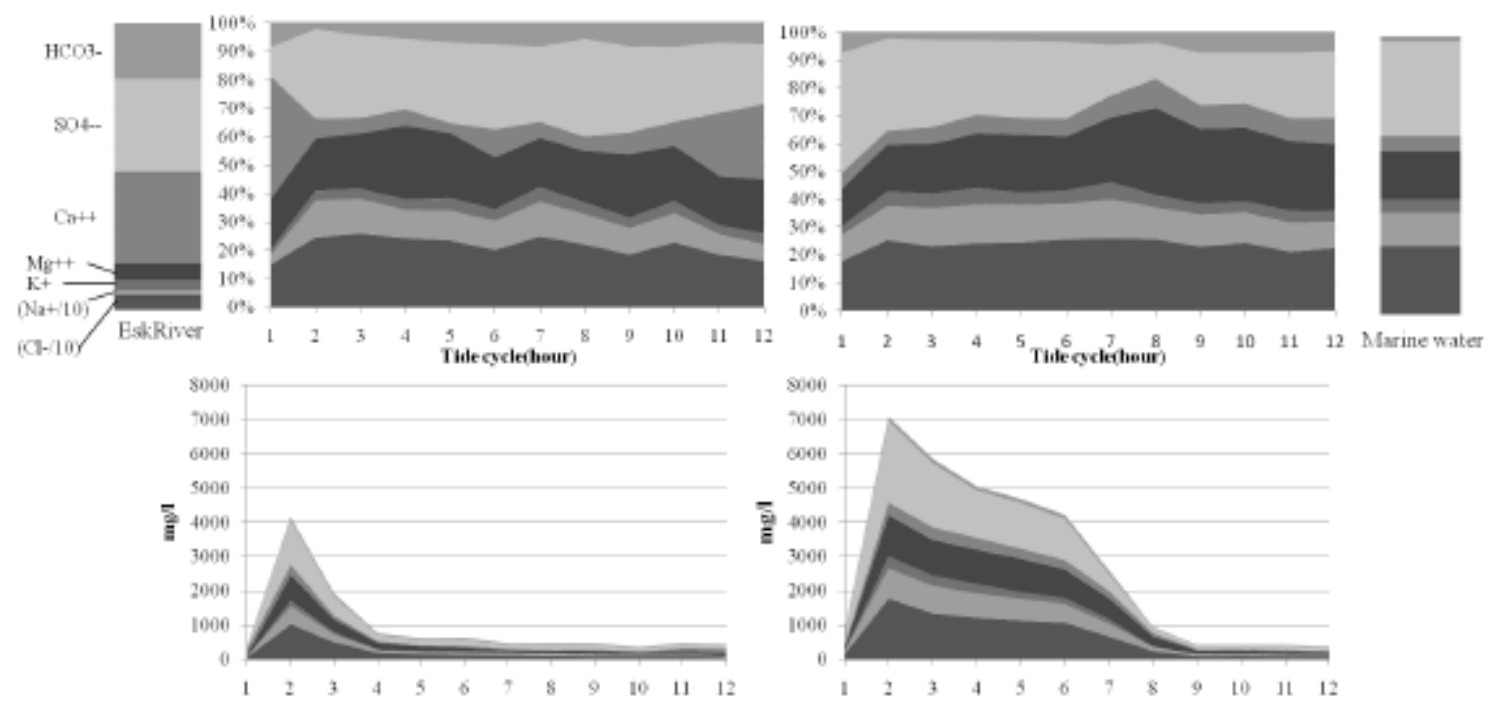

Esk estuar-upper

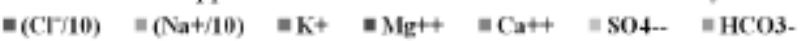

Figure 3. Normalised and absolute concentrations of the common cations and anions at the two sampling stations on the Esk arm of the Ravenglass estuary; Esk estaury-lower is towards the sea while Esk estuary-upper is towards the head of the estuary. The sodium and chloride concentrations were both divided by ten to allow the variations of the other ions to be visible. The normalised data show how the relative concentrations vary with time; the absolute concentrations illustrate the timing of high tide and how quickly the sea water is replaced by river water at the two sampling stations. 

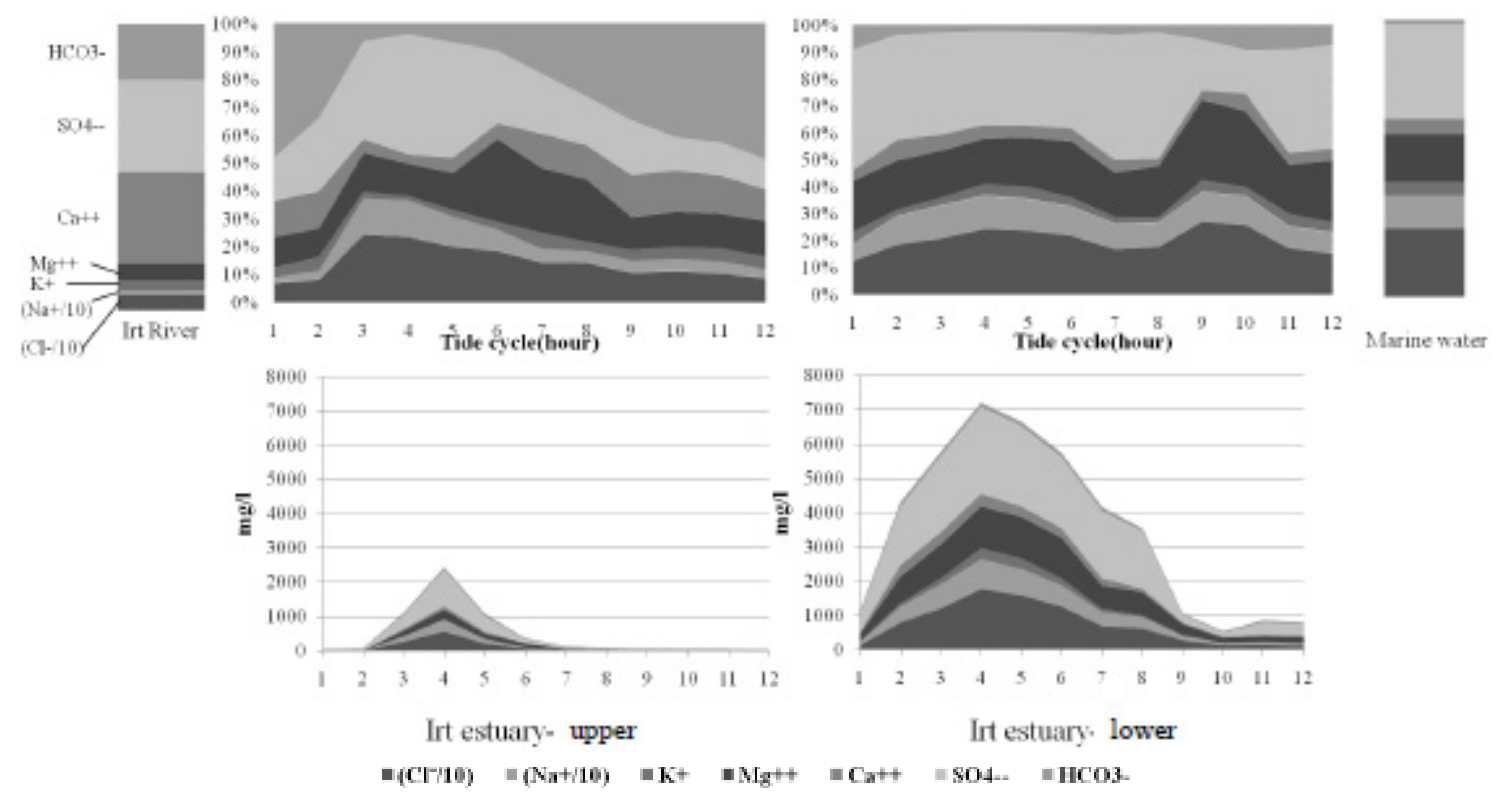

Figure 4. Normalised and absolute concentrations of the common cations and anions at the two sampling stations on the Irt arm of the Ravenglass estuary; Irt estaury-lower is towards the sea while Irt estaury-upper is towards the head of the estuary. The sodium and chloride concentrations were both divided by ten to allow the variations of the other ions to be visible. The normalised data show how the relative concentrations vary with time; the absolute concentrations illustrate the timing of high tide and how quickly the sea water is replaced by river water at the two sampling stations.

To further examine the relative concentrations with time, the data at each site were normalised to $100 \%$ (again using $\mathrm{Na} / 10$ and $\mathrm{Cl} / 10$ ) at each time step and then plotted as a function of relative concentration versus time. To further highlight relative behaviour each river composition and the seawater sample were also normalised and compared to the time data from the two sites in each estuary (Figs. 3 and 4). These normalised plots versus time show that at high tide, at each site, the water broadly resembles seawater (the relative proportions of the ions in the estuary are much the same as the seawater). However, at low tide, the relative proportions of the ions in the estuary are not particularly like those in the river water samples suggesting the geochemical addition or removal of some species in the estuary. When chloride and sodium are plotted versus TDS, they have excellent correlations, presumably because they are largely conservative species (i.e., they are not particularly involved in geochemical processes). While the trend is not quite as perfect, there appear to be good 1:1 correlations between magnesium and potassium and TDS suggesting that these cations are also largely conservative in the estuary. In comparison to species such as chloride, calcium and alkalinity appear to be non-conservative species in the estuary (Figs. 3 and 4). Sulphate concentrations also appear to be non-conservative developing relatively low concentrations under low tide conditions at the up-estuary sites.

To test this further, all species have been plotted against (x-axis) conservative chloride concentrations for all sites with the nominal 1:1 conservative mixing line added for reference on each graph. Because it is here now assumed that chloride can be neither added nor removed by geochemical processes, values above the line suggest addition of that species while values below that line suggest removal of that species (Fig. 5). Thus sodium values all plot on, or very close to, the 1:1 lines. Similarly, magnesium and potassium values also plot very close to the 1:1 lines. Sulphate concentrations seem to lie close to the 1:1 line for two up-estuary sites at Esk-upper and Irt-upper but there appears to be an excess sulphate at Irt-Lower and a shortfall at Esk- lower. Thus the two more marine estuary sites thus show contrasting behaviour. Almost all alkalinity values $\left(\mathrm{HCO}_{3}\right)$ lie above the 1:1 mixing line although the low and high chloride concentrations do appear like the fluvial and marine end-members. Overall the alkalinity data describe an arc above the 1:1 line suggesting significant addition of $\mathrm{HCO}_{3}$ within the estuary itself. Calcium values mostly lie close to the 1:1 line but with some scatter in the values. Calcium values have also been plotted against alkalinity for all sites with a nominal 1:1 conservative mixing line added for reference on each graph; these graphs suggest an excess of $\mathrm{HCO}_{3}$ relative to calcium in the estuary.

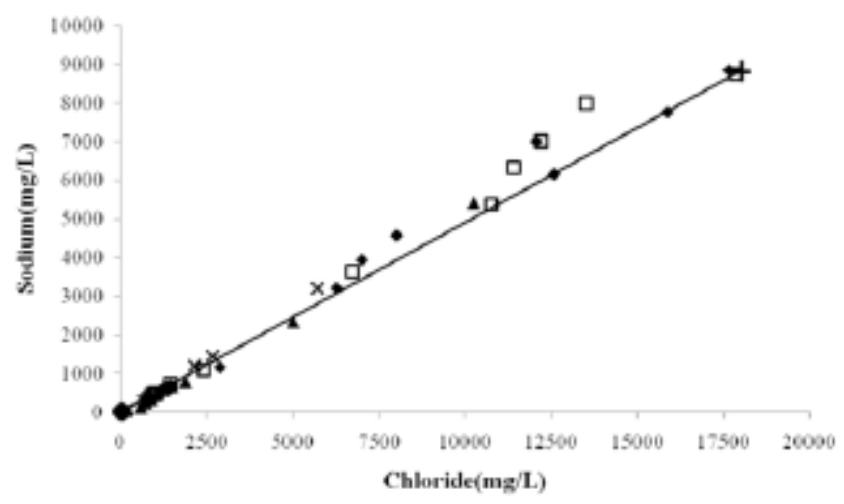



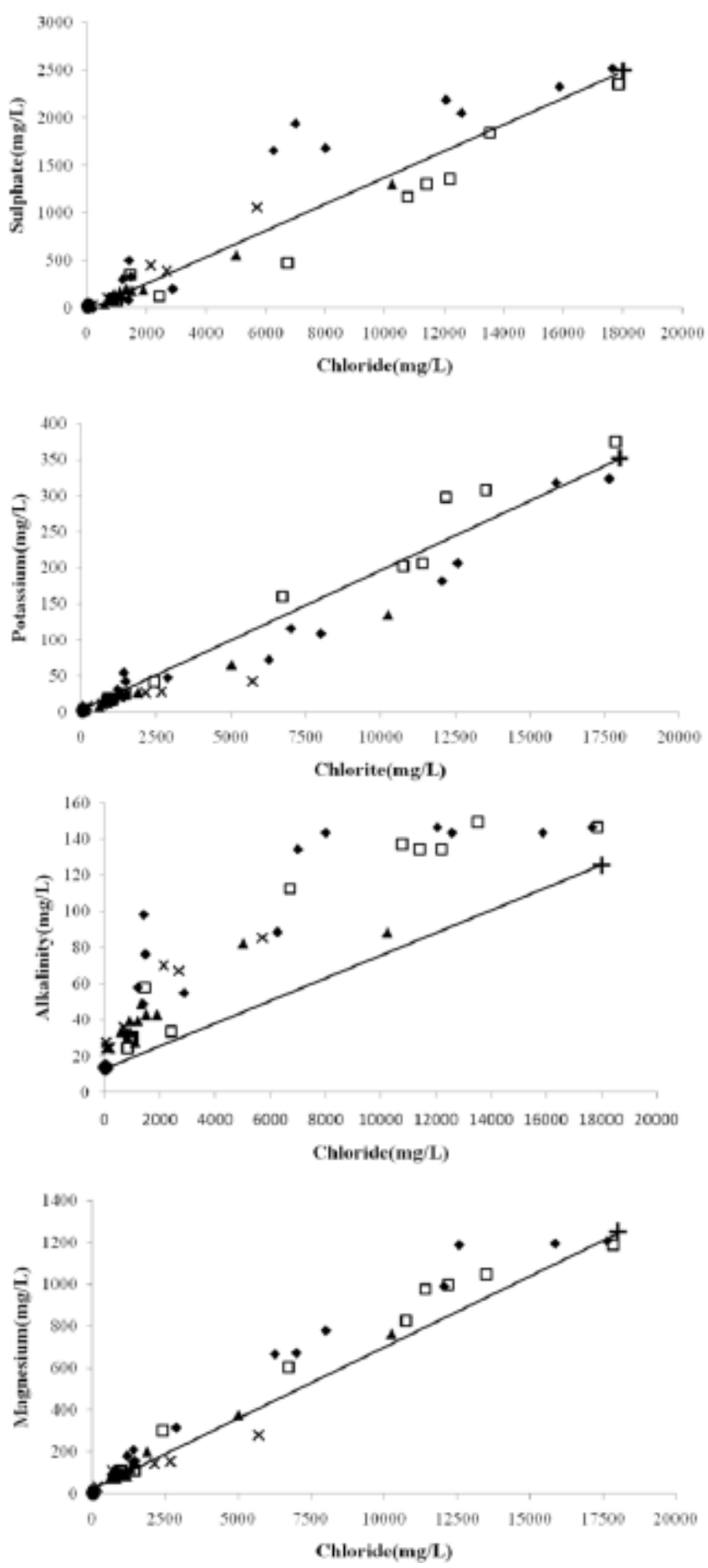

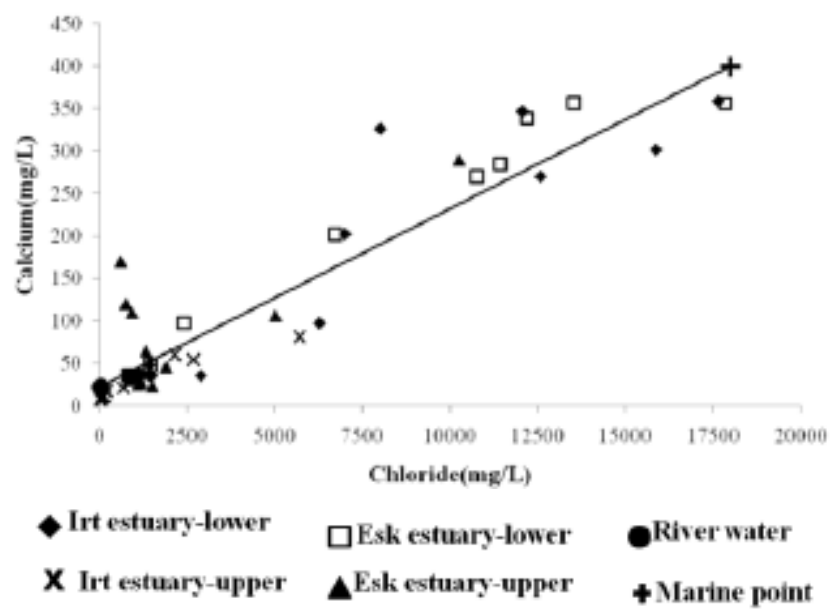

Figure 5. Ion concentration vs. chloride and modelled 1:1 correlation line that describes the theoretical conservative behaviour of each ion, at the Irt estaury-lower and Irt estaury-upper from Irt andEsk estuary-upper and Esk estaury-lower from Esk sampling stations. Calcium, alkalinity and Sulphate broadly show a non-conservative behaviour. Sulphate seems is taken from the water at the Esk and is added to the estuarine water at the Irt.

\section{Results of Iron Analysis}

The fluvial samples had iron concentrations for waters (acidified to $\mathrm{pH} 3$ and then immediately filtered, i.e. within 5 minutes) of $0.29 \mathrm{mg} / \mathrm{L}$ for the River Esk and $0.67 \mathrm{mg} / \mathrm{L}$ for the River Irt (Table 1). This method releases iron held in colloids and floccules and is a true representation of the amount of aqueous iron transported by the river. The marine-end member is assumed to have an iron concentration of $0.01 \mathrm{mg} / \mathrm{L}[5]$ and Table 1 .

The estuary water samples were also treated in the same way for iron determination. The concentrations of iron, as a function of time through tide cycles at the four stations, are represented in Figure 6. For all stations in the estuary, high tide time sees the lowest iron concentrations confirming that the incoming seawater bears very little iron, as expected. For the Esk estuary, the estuary waters seem to have their highest iron concentrations between high and low tide. For the Irt estuary the highest iron concentrations seem to be at low tide, although there are elevated values between high and low tides for both stations on the Irt estuary.

Especially at the Esk-upper site, there is a crude inverse relationship between $\mathrm{pH}$ and iron concentration. At high $\mathrm{pH}$, the iron concentration tends to be low while at low $\mathrm{pH}$, the iron concentration tends to be high.. 

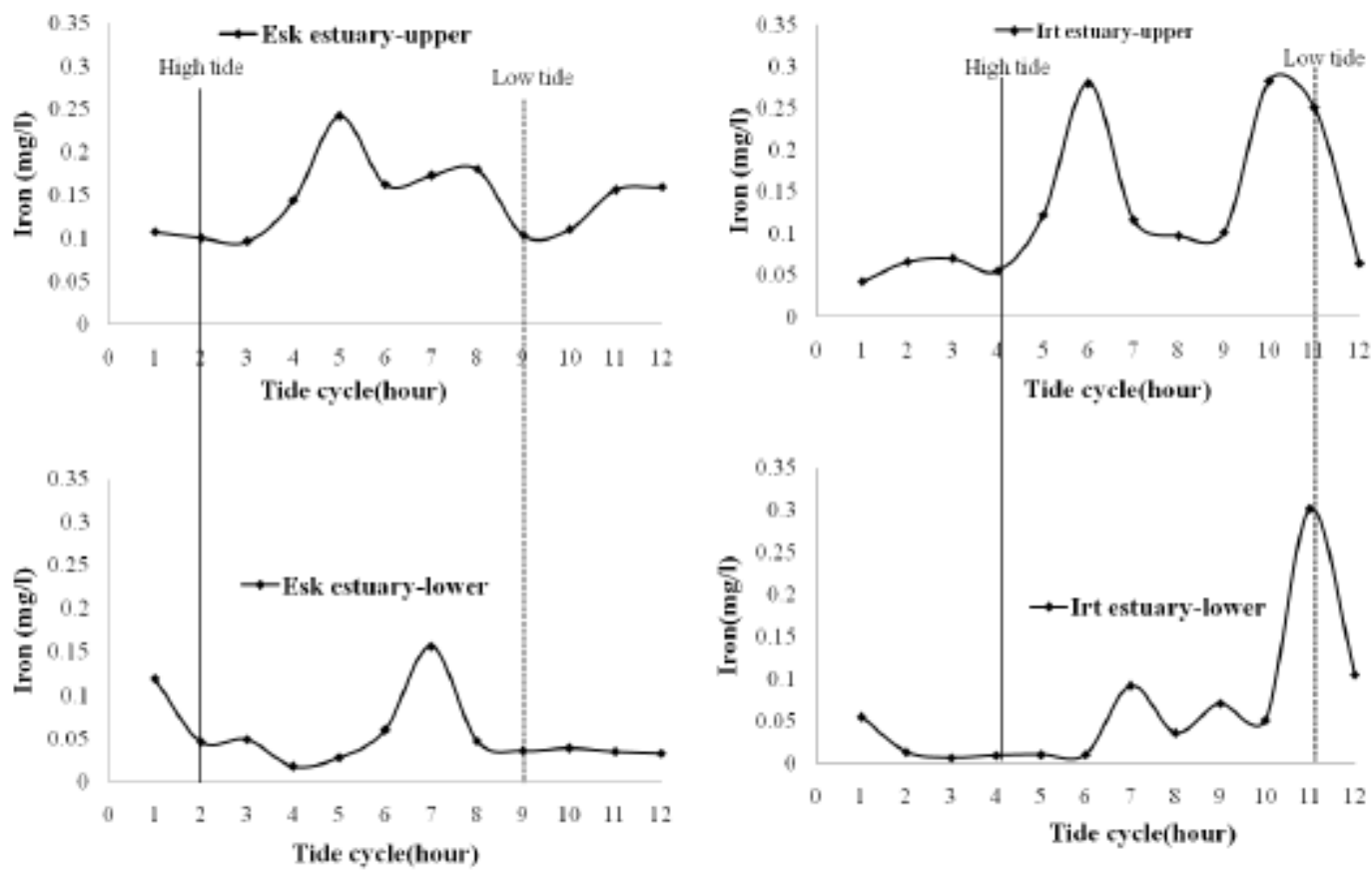

Figure 6. Iron concentration $(\mathrm{mg} / \mathrm{L})$ in the four Ravenglass estuary water sampling stations during tide cycles. Irt estaury-upper station in the fresh water-dominated part (up-estuary) of the Irt estuary, iron concentration shows dissolved iron increases after high tide and the maximum concentration is at low tide. Irt estaury-lower, marine water-dominated part (down-estuary) of the Irt estuary, dissolved iron concentration significantly is low at high tide (saline water) and increases toward low tide (fresh waters). Church, fresh water-dominated part (up-estuary) of the Esk estuary, dissolved iron concentration shows variation during the tide cycle with the maximum between high and low tide. Esk estuary-lower, marine water-dominated part (down-estuary) of the Esk estuary, the highest dissolved iron concentration is before low tide and at high tide, dissolves iron is low as well. Overall, the maximum iron concentration in the Irt estuary system is about twice the iron concentration in the Esk part of the estuary. Also, dissolved iron concentration around high tide is low and increases towards low tide conditions.

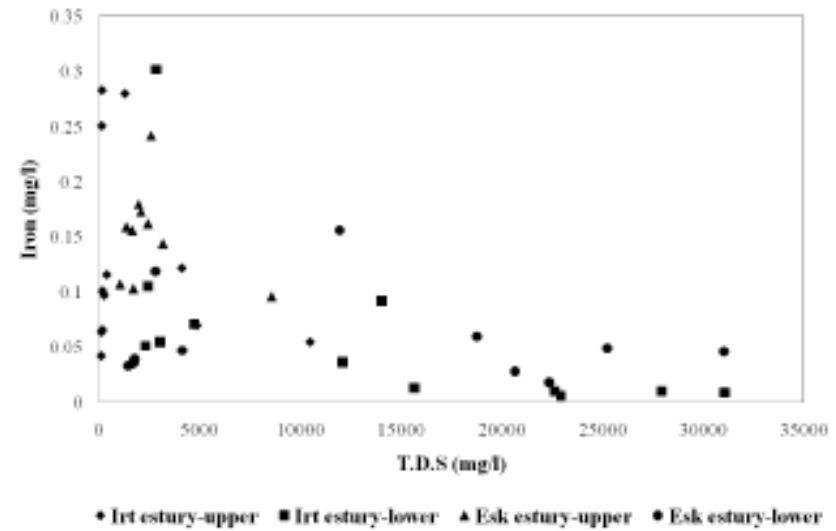

Figure 7. Iron concentration $v s$. calculated salinity (total dissolved solids: T.D.S.) for four stations across the Ravenglass estuary. Overall iron behaves non-conservatively in the Ravenglass estuary since the data plot below a mixing line between seawater $(35,000 \mathrm{mg} / \mathrm{L}$ salinity and $0.01 \mathrm{mg} / \mathrm{L}$ iron) and river water samples with their salinity of $<100 \mathrm{mg} / \mathrm{L}$ and iron concentrations of 0.29 to $0.67 \mathrm{mg} / \mathrm{L}$.

The concentrations of iron in the estuary water samples have been plotted as a function of salinity (total dissolved solids; Fig. 7). This shows that high salinity estuary water equates to low iron concentrations. Conversely, low salinity estuary water samples have the highest iron concentrations. Seawater has a very low concentration of iron $(0.01 \mathrm{mg} / \mathrm{L}$; Table 1) and the river water have much higher iron concentrations (Table 1) so that the decrease with salinity in the estuary is not surprising. However, the estuary waters do not lie on a 1:1 conservative mixing line; they have much less iron than would be expected for this situation. Even by the time the estuary waters have mixed with $1 / 7$ seawater (having a salinity of salinity of $5000 \mathrm{mg} / \mathrm{L}$ ) they have lost the vast majority of their iron (transported in by the rivers). In the case of the River Irt (starting at $0.67 \mathrm{mg} / \mathrm{L}$ ), the waters have lost $80 \%$ of their iron. Almost all the elevated iron concentrations are found in the up-estuary (river-dominated) sites at low to very salinity. The Esk estuary-lower site appears to be slightly different to the other three sites having slightly elevated iron concentrations (e.g. in comparison to Irt-Lower), but still having non-conservative behaviour relative to iron.

\section{Discussion}

\section{Controls on Estuary Water Geochemistry}

Salinity and conservative species (chloride, sodium and possibly magnesium and potassium) increase and decrease in concentration through the tide cycle (Figs. 3 and 4). At high tide, the estuary water at the Esk-Lower and Irt-Lower sites effectively is pure seawater. The upper estuary Esk-upper and Irt-upper sites achieve lower maximum concentrations 
and overall salinity than the lower estuary Esk-Lower and Irt-Lower sites.

At high tide, the upper estuary Esk-upper and Irt-upper sites have species proportions that makes the estuary look like seawater (compare the marine species proportions on the right of Figs. 4 and $\mathrm{c}$ to the high tide species proportions at these sites) suggesting that a simple seawater-river water mixing process has occurred $[9,23]$. Although at low tide, the Esk-upper and Irt-upper sites fall to very low salinities, the estuary waters are not the same as the incoming river waters in terms of species proportions. Thus, the Irt-upper site has an excess of alkalinity suggesting that $\mathrm{HCO}_{3}$ has been added, for example by biological processes, while the Esk-upper site approaching high tide has a shortfall of alkalinity and an excess of calcium suggesting that $\mathrm{HCO}_{3}$ has been removed, for example by calcite precipitation processes.

Sulphate concentrations also seem to be non-conservative with possible relative decreases after high tide at Esk-Lower especially (Figs. 3 and 5) and with a possible relative increase at Irt-Lower (Figs. 4 and 5). Sulphate could be lost from the water by bacterial sulphate reduction $[10,24]$ leading to the creation of sulphide species and the possible growth of Fe-sulphide minerals. Thus apparent loss of aqueous sulphate could be important since it potentially influences iron geochemistry. Conversely sulphate could be added to the estuary water by oxidation of sulphide minerals (e.g. during sediment erosion down to the redox interface in the sediment) with the concomitant possible release of iron to get involved with non-sulphide geochemical processes.

The non-conservative behaviour of iron on mixing river water with seawater has already been established (Fig. 7). This is not surprising since a similar pattern has been illustrated for several other estuaries (e.g. Mayer [25]) The possible controls on the relative loss of iron and its relationship to water geochemistry, the position this occurs in the estuary and the timing of iron loss during the tide cycle will now be discussed.

\section{Salinity and Iron Removal}

Salinity has an important effect on the surface charge and stability of the colloidal particles; in saline waters, Fe-colloids lose their charge and become less repellent to each other $[16,25]$. It has been suggested that iron agglomerates to form colloids during the mixing of river water and seawater $[19,25,35]$. Iron concentrations in the River Irt and the River Esk fall as soon as they mix with any estuary water suggesting that elimination of iron from the water thus happens at the earliest stage of rivers entering estuaries, i.e. relatively high up the tidal creeks and channels (Fig. 7). River water-seawater mixing occurs at different positions in the estuary as a function of the tide cycle; dissolved iron concentrations at a given site are lowest at high tide (Fig. 6). Thus as saline estuary sweeps up the tidal channels at high tide, the point of Fe-loss will also presumably sweep up the tidal channels.

pH and Iron Elimination
Elimination of dissolved iron by flocculation and precipitation of iron oxides and hydroxides has been reported to be a possible result of increasing $\mathrm{pH}[35,39]$ as well as salinity (ionic strength). Higher $\mathrm{pH}$ values, such as found in seawater relative to river water (Table 1), increase the chance of generating solid-phase ferric iron oxide or hydroxide, thus eliminating iron from the water as a direct result of $\mathrm{pH}$ change $[35,39]$. At $\mathrm{pH}$ values below 6.5 the oxidation rate is slow, thus when relatively low-pH river mixes with higher-pH marine water, iron is oxidized and precipitated as hydrated ferric oxide $[8,35,39]$. $\mathrm{pH}$ at high tide tends to be higher than low tide all across the Ravenglass estuary and it is compatible with iron elimination from the water in the estuary at high tide conditions.

\section{Flocculation}

Despite the possible role of redox processes, the oxidation of ferrous iron has been reported to be an insignificant mechanism for iron removal in estuaries [8,17]. Conversely, flocculation is typically concluded to be the main mechanism of removal iron in the estuaries [8,25,35,37]. In this matter, high tide at all stations has the highest $\mathrm{pH}$ and salinity, the flocculation and loss of iron in the form of oxide or hydroxide can happen [4] (Fig. 7). Small and therefore light floccules potentially remain suspended in the estuary water and may be taken out into the sea at low tide. Irt and Esk Rivers supply relatively large amounts of dissolved iron (Table 1) to their estuaries and because of the dimension of the estuaries (small estuaries), high energy environments, and variation between high and low tide, the suspended iron floccules can be transported and some of the settled floccules may be washed down the tidal channels and creeks towards the sea at low-tide, and then be flushed back to the estuaries during a rising tide. The River Irt supplies almost twice as much dissolved iron to the estuary relative as the River Esk (Table 1).

Dissolved iron concentrations in the Irt at Irt estaury-upper and Irt estaury-lower fall dramatically at high tide (down to $<0.05 \mathrm{mg} / \mathrm{L}$ ), presumably due to the creation of abundant floccules (Fig. 6, 7). Elimination of iron in the Esk estuary also shows a drop from fresh water to the saline water, however, the collapse of dissolved iron concentration during high tide is not as dramatic as the Irt estuary possibly because less iron is being supplied by the Esk. The presence of dissolved iron in the marine-dominated part of the Esk estuary (Esk estuary-lower) soon after high tide, and at a similar time of the river water-dominated Esk-upper site, may be due to the transport of abundant Fe floccules, produced in the Fe-rich Irt at low tide and transported down tidal channels and creeks, then being flushed into the Esk arm of the estuary by the incoming tide. The Ravenglass estuary is a macro-tidal estuary, with a tidal range of over $7 \mathrm{~m}$ on spring tides and also the estuary has relatively high tidal discharges and velocities [5], but the rivers that feed into it have relatively low discharges [2]. Consequently tidal discharges and velocities in the Ravenglass estuary are relatively high [2], resulting in the penetration of seawater 
(and mixed seawater-and outgoing Irt River water) far up the Esk arm of the estuary. The saline state persists for long periods after high tide in the middle reaches of the estuaries especially in the Esk estuary Lower (Fig. 3) but also in the Irt estuary (Fig. 4).

An association between dissolved iron and dissolved organic matter (humic acid) [18] in terms of the aggregation of the iron colloids has been reported [31,38] and also significant role of cation exchange capacities on organic matter flocculation and iron aggregation have been revealed [38]. The greatest removal of dissolved iron in the Ravenglass estuary occurs as TDS approaches $\sim 5000 \mathrm{mg} / \mathrm{L}$ (Fig. 7; [2,25,38].

Iron rich colloids that are flushed from the rivers out into seawater-influenced estuary and altered to aggregates and floccules must be removed from the water column by gravitational settling. The iron leaves the aqueous part of the system once salinity exceeds $\sim 5000 \mathrm{mg} / \mathrm{L}$ and the $\mathrm{pH}$ starts to increase and presumably becomes part of the sediment (mineral) part of the system.

\section{Sulphate-iron Geochemistry}

It was noted that sulphate concentrations are relatively depleted in parts of the Ravenglass estuary in comparison to conservative mixtures of seawater and river water (Figs. 3, 4, and 5). It was concluded that this may be due to localised bacterial sulphate reduction converting sulphate into sulphide. High iron concentrations are only possible at low sulphate concentrations. It is interesting to speculate that elevated sulphate concentrations leaves the possibility of elevated sulphide concentrations so that at least some dissolved iron may be lost from the water by Fe-sulphide mineral formation. At present the mineral (or at least solid) form of the flocculated iron remains unknown so this possibility cannot be assessed further.

\section{Conclusions}

In the lower to middle reaches of the Ravenglass estuary at high tide salinity reaches seawater values and remains elevated long after high tide but then falls to very low values at low tide. Salinity reaches between a quarter and a half of seawater salinity about $1 \mathrm{~km}$ further up-estuary and quickly falls back to low values soon after high tide.

Ravenglass estuary water is a conservative mixture between river water and seawater as far as chloride, sodium, potassium and magnesium are concerned, Alkalinity is non-conservative and is added, probably by biogeochemical processes, in the estuary, Calcium is also non-conservative, possibly being lost from the water (as alkalinity increases) due to calcite growth (possibly as shells), Sulphate is present in seawater-like proportions at high but may be lost from the water at low tide, possibly by sulphate reduction processes. It is also possible that there is local sulphate addition, possibly by sulphide mineral precipitation.

Iron concentrations are lowest at high tide at all sampling sites on the Ravenglass estuary. Iron concentrations are highest at low tide for the Irt arm of the estuary but are highest on the falling tide between high and low tide .

The River Irt contains twice as much dissolved iron as the River Esk. Iron concentrations are much lower in the estuary samples than in the feeding rivers so that dissolved iron undergoes large-scale accumulation in the Ravenglass estuary.

Iron concentrations in estuary samples decrease rapidly as salinity increases with low iron concentrations in all estuary samples once salinity exceeds 5,000 $\mathrm{mg} / \mathrm{L}$. Iron concentrations also decrease as $\mathrm{pH}$ increases. The loss of iron is presumably due to flocculation of colloidal iron oxides, hydroxides and iron-organic complexes as increasing salinity reduces the surface charge of colloids and thus permits aggregation. It is also possible that sulphate reduction may locally lead to Fe-sulphide creation within the estuary.

Fluvial dissolved iron does not behave conservatively on mixing with seawater; most iron is lost from the water column at an early stage of river water mixing with estuary water. The site of primary iron-loss from the water occurs towards the heads of estuaries but this site will move as a function of time within the tide cycle.

Given that the Esk has highest iron concentrations between high and low tide, it is likely that iron, either dissolved or as fine floccules, is swept from the iron-rich Irt arm of the estuary into the iron-poor Esk arm soon after high tide.

Iron colloids become immobilised in the estuary surface sediments then in association with organic matters and reduction media becomes mobilised and neo minerals can be formed.

\section{Acknowledgements}

This study could not have been completed without the help and assistance of many people. I would like to add a general note of thanks to everyone I know in school of Environmental sciences at the University of Liverpool. I would like to express my deep and sincere gratitude to Richard H. Worden, Dave Hodgson and James Utley. Also I would like to thank people at chlorite consortium (ExxonMobil, Chevron, ConoccoPhilips, Eni, Petrobras, BP, Shell and Statoil) for all their supports and academic comments.

\section{REFERENCES}

[1] Aller, R., Mackin, J. and Cox, R., 1986. Diagenesis of Fe and $\mathrm{S}$ in Amazon inner shelf muds: apparent dominance of $\mathrm{Fe}$ reduction and implications for the genesis of ironstones. Continental Shelf Research, 6(1-2): 263-289.

[2] Assinder, D.J., Kelly, M. and Aston, S.R., 1985. Tidal 
variations in dissolved and particulate phase radionuclide activities in the Esk Estuary, England, and their distribution coefficients and particulate activity fractions. Journal of Environmental Radioactivity, 2(1): 1-22.

[3] Bale, A. and Morris, A., 1981. Laboratory simulation of chemical processes induced by estuarine mixing: the behaviour of iron and phosphate in estuaries. Estuarine, Coastal and Shelf Science, 13(1): 1-10.

[4] Balls, P., Laslett, R. and Price, N., 1994. Nutrient and trace metal distributions over a complete semi-diurnal tidal cycle in the Forth estuary, Scotland. Netherlands Journal of Sea Research, 33(1): 1-17.

[5] Bousher, A., 1999. Ravenglass Estuary: Basic characteristics and evaluation of restoration options. Restrad-Td, 12(980132): 03.

[6] Boyle, E. et al., 1974. On the chemical mass-balance in estuaries. Geochimica Et Cosmochimica Acta, 38(11): $1719-1728$.

[7] Boyle, E., Edmond, J. and Sholkovitz, E., 1977a. The mechanism of iron removal in estuaries. Geochimica Et Cosmochimica Acta, 41(9): 1313-1324.

[8] Boyle, E.A., Edmond, J.M. and Sholkovitz, E.R., 1977b. The mechanism of iron removal in estuaries. . Geochim. Cosmochim. Acta., 41: 1313-1324.

[9] Bull, K. and Hall, J., 1986. Aluminium in the Rivers Esk and Duddon, Cumbria, and their tributaries. Environmental Pollution Series B, Chemical and Physical, 12(3): 165-193.

[10] Burton, J. and Liss, P., 1976. Estuarine chemistry. Academic. London. GB.

[11] Caccavo Jr, F., Blakemore, R. and Lovley, D., 1992. A hydrogen-oxidizing, $\mathrm{Fe}$ (III)-reducing microorganism from the Great Bay Estuary, New Hampshire. Applied and Environmental Microbiology, 58(10): 3211.

[12] Coleman, M., Hedrick, D., Lovley, D., White, D. and Pye, K., 1993. Reduction of Fe (III) in sediments by sulphate-reducing bacteria. Nature, 361: 436-438.

[13] Drever, J., 1982. Geochemistry of natural waters. Prentice-Hall, Inc., Englewood Cliffs New Jersey.

[14] Eckert, J. and Sholkovitz, E., 1976. The flocculation of iron, aluminium and humates from river water by electrolytes. Geochimica Et Cosmochimica Acta, 40(7): 847-848

[15] Ehrenberg, S., 1993. Preservation of anomalously high porosity in deeply buried sandstones by grain-coating chlorite: examples from the Norwegian continental shelf. AAPG Bulltein, 77: 1260-1260.

[16] Escoube, R., Rouxel, O.J., Sholkovitz, E. and Donard, O.F.X., 2009. Iron isotope systematics in estuaries: The case of North River, Massachusetts (USA). Geochimica Et Cosmochimica Acta, 73(14): 4045-4059.

[17] Fan, D. et al., 2008. Authigenic iron oxide formation in the estuarine mixing zone of the Yangtze River. Geo-Marine Letters, 28(1): 7-14.

[18] Fox, L., 1983. The removal of dissolved humic acid during estuarine mixing. Estuarine, Coastal and Shelf Science, 16(4): 431-440.
[19] Gerringa, L.J.A. et al., 2007. Kinetic study reveals weak Fe-binding ligand, which affects the solubility of $\mathrm{Fe}$ in the Scheldt estuary. Marine chemistry, 103(1-2): 30-45.

[20] Gibbs, R., Tshudy, D., Konwar, L. and Martin, J., 1989. Coagulation and transport of sediments in the Gironde Estuary. Sedimentology, 36(6): 987-999.

[21] Head, P., 1985. Practical estuarine chemistry: a handbook. Cambridge University Press.

[22] Huthnance, J. et al., 1993. Towards Water Quality Models and Discussion. Philosophical Transactions: Physical Sciences and Engineering, 343(1669): 569-584.

[23] Ixer, R., Turner, P. and Waugh, B., 1979. Authigenic iron and titanium oxides in triassic red beds:(St. Bees Sandstone), Cumbria, Northern England. Geological Journal, 14(2): 179-192.

[24] Johnston, S.G. et al., 2011. Iron geochemical zonation in a tidally inundated acid sulfate soil wetland. Chemical Geology, 280(3-4): 257-270.

[25] Mayer, L., 1982. Retention of riverine iron in estuaries. Geochimica Et Cosmochimica Acta, 46(6): 1003-1009.

[26] Morad, S., Al-Ramadan, K., Ketzer, J.M. and De Ros, L.F., 2010. The impact of diagenesis on the heterogeneity of sandstone reservoirs: A review of the role of depositional facies and sequence stratigraphy. AAPG BULLETIN, 94(8): $1267-1309$.

[27] Moseley, F., 1978. the geology of the lake district. Yorkshire Geol. Soc., occasional publication No.3.

[28] Mosley, L., Hunter, K. and Ducker, W., 2003. Forces between colloid particles in natural waters. Environ. Sci. Technol, 37(15): 3303-3308.

[29] Odin, G., 1988. Green marine clays: oolitic ironstone facies, verdine facies, glaucony facies, and celadonite-bearing facies: a comparative study. Elsevier Science Ltd.

[30] Olausson, E. and Cato, I., 1980. Chemistry and biogeochemistry of estuaries. John Wiley of Sons.

[31] Ouddane, B., Skiker, M., Fischer, J. and Wartel, M., 1999. Distribution of iron and manganese in the Seine river estuary: approach with experimental laboratory mixing. Journal of Environmental Monitoring, 1(5): 489-496.

[32] Rouxel, O., Sholkovitz, E., Charette, M. and Edwards, K.J., 2008. Iron isotope fractionation in subterranean estuaries. Geochimica Et Cosmochimica Acta, 72(14): 3413-3430.

[33] Roy, M., Martin, J.B., Cherrier, J., Cable, J.E. and Smith, C.G., 2010. Influence of sea level rise on iron diagenesis in an east Florida subterranean estuary. Geochimica Et Cosmochimica Acta, 74(19): 5560-5573.

[34] Roy, M., Martin, J.B., Smith, C.G. and Cable, J.E., 2011. Reactive-transport modeling of iron diagenesis and associated organic carbon remineralization in a Florida (USA) subterranean estuary. Earth and Planetary Science Letters, 304(1-2): 191-201.

[35] Sholkovitz, E., 1978. The flocculation of dissolved Fe, Mn, $\mathrm{Al}, \mathrm{Cu}, \mathrm{Ni}, \mathrm{Co}$ and $\mathrm{Cd}$ during estuarine mixing. Earth and Planetary Science Letters, 41(1): 77-86.

[36] Sholkovitz, E., 1979. Chemical and physical processes 
controlling the chemical composition of suspended material in the River Tay Estuary. Estuarine and Coastal Marine Science, 8(6): 523-545.

[37] Sholkovitz, E., Boyle, E. and Price, N., 1978. The removal of dissolved humic acids and iron during estuarine mixing. Earth and Planetary Science Letters, 40(1): 130-136.

[38] Sholkovitz, E.R., 1976. Flocculation of Dissolved Organic and Inorganic Matter during Mixing of River Water and Seawater. Geochimica Et Cosmochimica Acta, 40(7): 831-845.

[39] Spiteri, C., Regnier, P., Slomp, C.P. and Charette, M.A., 2006. $\mathrm{pH}$-Dependent iron oxide precipitation in a subterranean estuary. Journal of Geochemical Exploration, 88(1-3):
399-403.

[40] Stow, C., Roessler, C., Borsuk, M., Bowen, J. and Reckhow, K., 2003. Comparison of estuarine water quality models for total maximum daily load development in Neuse River Estuary. Journal of Water Resources Planning and Management, 129: 307.

[41] Strong, G. et al., 1994. The petrology and diagenesis of Permo-Triassic rocks of the Sellafield area, Cumbria, Yorkshire Geological Society. Geological Society of London, pp. 77.

[42] Sutcliffe, D. and Carrick, T., 1988. Alkalinity and pH of tarns and streams in the English Lake District (Cumbria). Freshwater Biology, 19(2): 179-189. 